\title{
Efficient Microorganisms in lettuce cultivation
}

Westefann dos Santos Sousa ${ }^{1}$

José Roberto Verginio de Pontes ${ }^{2}$

Osmanny Francisco Pereira de Melo $^{3}$

\section{Abstract}

Efficient Microorganisms are shown to be an effective, alternative, sustainable, safe, and low-cost technique to increase the productivity of organic foods, and their use is a good option for agroecological management. Based on this context, this work had as main objective to evaluate the efficiency of the application of a biological cocktail from Efficient Microorganisms in the cultivation of lettuce. In the capture of the Efficient Microorganisms and the manufacture of the biological cocktail, a methodology proposal in the agroecology used by Brazilian Ministry of Agriculture, Cattle and Supplying (MAPA, in Portuguese, Ministério da Agricultura, Pecuária e Abastecimento). The adopted experimental design was randomized blocks containing 8 blocks and 3 treatments. The T1 treatment, application of the Efficient Microorganisms, obtained a greater fresh mass of the aerial part of the plants sampled in the two cycles, resulting in a higher productivity in tons/hectare. The results proved to be advantageous for the productivity of the lettuce that received application of the biological cocktail from Efficient Microorganisms, when the biomass parameters were analyzed.

Keywords: Lactuca sativa. Organic production. Biological cocktail.

\section{Introduction}

Organic food started to gain space in the vegetable market, since techniques that respect the environment and aim at food quality are used throughout the production process, no pesticides or any other type of product that may cause some damage to the health of producers and consumers are administered (PEREIRA et al., 2015).

Pereira et al. (2014) stated that one of the biggest challenges of organic production is the fertilization of crops. In this context, efforts have been made to replace mineral fertilizers with natural sources of nutrients, ensuring high productivity, maintaining the efficiency and sustainability of the production system. The authors affirmed the effectiveness of the use of Efficient Microorganisms (EMs) as an alternative, sustainable, safe and low cost technique to increase the productivity of organic foods, being its use a good option for agroecological management.

The product composed of Efficient Microorganisms had its origin in Japan and was developed by Professor Dr. Teruo Higa. According to Mitsuiki (2006), this organic technology has been used in organic agriculture since the 1980 s, and despite this product in its commercial form $\left(\mathrm{EM}^{\circledR}\right)$,

1 Universidade Estadual de Goiás (UEG), mestrando pelo Programa de Pós-Graduação em Produção Vegetal. westefannsantos@hotmail. com. Rodovia GO-330, Km 241, Anel Viário, Ipameri - GO.

2 Instituto Federal de Educação, Ciência e Tecnologia do Pará (IFPA), Campus de Conceição do Araguaia - PA. Professor Doutor. jrvpontes@hotmail.com.

3 Universidade Estadual de Goiás (UEG), mestrando pelo Programa de Pós-Graduação em Produção Vegetal. osmanny16@gmail.com. 
produced and distributed in Brazil by the Mokiti Okada Foundation, there is an empirical method to capture these Efficient Microorganisms and production of the biological cocktail (ANDRADE, 2011). For family farming, this technology might be more adaptable to local conditions, becoming accessible due to the low cost and the facilities of its production.

According to Andrade (2011), EM is composed of four distinct groups: Yeasts, which use substances necessary for plant growth; Actinomycetes, which act as a controller of fungi and pathogenic bacteria and also give plants greater resistance; Lactic acid-producing bacteria, which has the capacity to eliminate microorganisms that induce phytopathogenic diseases; photosynthetic bacteria, which is an independent and autonomous group, the useful substances developed by these bacteria include amino acids, nucleic acid, bioactive substances and sugars, which in addition to boosting plant growth, increase populations of other efficient microorganisms, such as nitrogen fixers, actinomycetes and mycorrhizal fungi.

Efficient microorganisms are known to favor mineralization and the availability of essential nutrients for plants, activating metabolism and root growth. According to Pugas et al. (2013), EM constitutes a set of organisms that, when added to the soil, increase their microbiological diversity, playing the role of inducing the decomposition of organic material and, consequently, releasing nutrients with greater efficiency for plants.

For this research, lettuce (Lactuca sativa L.) was chosen, as it is one of the most consumed leafy vegetables today, being grown in almost the whole country. In addition, it has an important role in the income of small producers, presenting a great commercial value and it can be sold directly at fairs (INAGAKI et al., 2011).

According to Sampaio (2013), lettuce, as well as other vegetables produced under organic techniques, can be just as productive as conventional ones, in addition to having a different price in marketing. Therefore, it is of utmost importance to deepen research on the application of agroecological techniques in the production of vegetables, aiming at the production of sustainable food, which can benefit the producer, the consumer and the environment.

Based on this context, this study had as its main objective to evaluate the application of a biological cocktail from Efficient Microorganisms in the cultivation of lettuce.

\section{Material and methods}

The research was carried out in the municipality of Conceição do Araguaia, Southeast Region of Pará, with municipal headquarters located at $08^{\circ} 16^{\prime} \mathrm{S} ; 4^{\circ} 16^{\prime} \mathrm{W}$ coordinates. The region's climate falls into the dry humid equatorial category in winter, type Aw. The average annual temperature is $26.1^{\circ} \mathrm{C}$, and it has an average annual rainfall of $1,734 \mathrm{~mm}$.

The study began in the first semester of 2018 and it was completed in the second semester of the respective year, under field conditions, on a property belonging to a vegetable-growing family in the municipality.

For the capture of the Efficient Microorganisms and the manufacture of the biological cocktail, it was adopted the methodology used by Leite and Meira (2016), reported in the agroecological records of the by Brazilian Ministry of Agriculture, Cattle and Supplying (MAPA, in Portuguese: Ministério da Agricultura, Pecuária e Abastecimento).

A substrate made with $1 \mathrm{~kg}$ of cooked rice without salt and without oil was used, spread on tiles and covered with a sombrite type canvas. Then, the location in the forest was chosen, and by 
removing the organic material from the soil, an opening was made to deposit the tiles containing the cooked rice. The containers were covered by the same organic material and left to rest for 15 days.

After the deadline, the tiles were discovered and the portions of rice were separated according to the colors of the molds, which covered the substrate. According to Leite and Meira (2016), pink, blue, yellow and orange molds are used as efficient microorganisms. The portions of rice with dark colors (gray, brown and black) were discarded in the forest itself, as they consist of non-beneficial microorganisms.

For the manufacture of the biological cocktail, the material of interest, captured in the forest with the aid of the substrate made of rice, was mixed and distributed in four $600 \mathrm{~mL}$ bottles, adding $50 \mathrm{~g}$ of brown sugar to each bottle and completing the volume with clean water. The bottles were closed, left in a shady place and opened every two days to remove the gas produced by the fermentation process of the microorganisms.

The biological cocktail was ready for use when there was no more gas production inside the bottles (from 10 to 20 days), and when the smell had a sweet and pleasant odor of lactic and acetic fermentation, with an orange color. Siqueira and Siqueira (2013) stated that this product, in its handmade form, can remain stored for up to one year, and when it has a bad smell, it should not be used in production.

The experimental design adopted was randomized blocks containing 8 blocks and 3 treatments. The treatments used were: T1 - weekly spraying of biological cocktail from the Efficient Microorganisms; T2 - weekly spraying of a mineral fertilizer (NPK 30-10-10); T3 - witness, without any fertilization.

Each block had $8 \mathrm{~m}^{2}$ and plots of $2.52 \mathrm{~m}^{2}$. The plots corresponding to each treatment, drawn and randomly distributed, were composed of 28 plants, with a spacing of $0.30 \mathrm{~m} \times 0.30 \mathrm{~m}$ between plants and lines.

For each plot of the $\mathrm{T} 1$ treatment, $5 \mathrm{~L}$ of biofertilizer were prepared with a mixture of $10 \mathrm{~mL}$ of the Efficient Microorganism stored in PET bottles, $10 \mathrm{~mL}$ of molasses and $5 \mathrm{~L}$ of water, according to the recommendations by Leite et al. (2016). The application of the biological cocktail was conducted weekly, in the volume of $5 \mathrm{~L}$ per application, in the coolest hours of the day, during the two cycles of the culture, from transplanting to harvest.

In the $\mathrm{T} 2$ treatment, each plot received $5 \mathrm{~L}$ of the mineral fertilizer syrup NPK 30-10-10 weekly. For the preparation of the syrup, according to the recommendation described on the product, $15 \mathrm{~g}$ of the formulated was used for $5 \mathrm{~L}$ of water.

In the application of the treatments, a plastic watering can with fine sieves was used. In the T3 treatment, no type of fertilization was used, being it considered the control. All treatments received daily irrigation in the same proportion, using the micro sprinkler system (ballerinas). Assessments were made on two consecutive lettuce cycles.

The variety of lettuce used in the experiment is Lucy Brown from the group "Americana Repolhuda". The seedlings were produced by sowing in styrofoam trays with 128 cells, using commercial substrate, in protected cultivation (greenhouse with plastic film). The beds, also in protected cultivation, were prepared concurrently with the formation of the seedlings, remaining in "rest" until the moment of transplanting, which occurred 20 days after sowing. The soil preparation was manual, and the operation was common to all treatments.

During the culture cycles, cleaning was performed to manual (weeding) of weeds, in order to avoid competition for light and nutrients as much as possible, and no chemical product was used for phytosanitary control. Harvest was carried out 30 days after transplanting the seedlings, in both crop cycles. 
Three representative samples of lettuce were selected in each plot, preferably from the central part, excluding the edges, resulting in 72 sample plants. For them, it was carried out the physical analysis of the plant part, to verify the following parameters: fresh mass of the aerial part (FMAP), obtained by weighing the leaves and stalk; fresh root mass (FRM), obtained by weighing the roots; number of leaves per plant (NLP), obtained by counting all commercial leaves over $5 \mathrm{~cm}$ in length; stem length (SL), obtained by using a ruler; number of viable plants per plot (NVPP), at which the number of commercial plants in each plot of the experiment was counted.

Therefore, it was possible to estimate the productivity of the plants submitted to the different treatments, the total sum of the fresh mass values of the aerial part of the plants sampled in the plots of each treatment and the total amount of viable plants in all plots were obtained. Taking into account that 8 plots of a given treatment resulted in $20 \mathrm{~m}^{2}$, the values of fresh mass of all sampled plants $\left(\mathrm{km}^{2}\right)$ were extrapolated to tons $\left(\mathrm{t} \mathrm{ha}{ }^{-1}\right)$.

All the results of the evaluated parameters were analyzed by means of analysis of variance (ANOVA) and later by the Tukey's means comparison test at the level of $5 \%$ probability. These analyzes were performed in the Sisvar program, version 5.6 (FERREIRA, 2001).

\section{Results and discussion}

According to Table 1, with the significance level of the variables arranged, it is possible to say that in the first cycle of lettuce, at least, one of the treatments showed a significant difference at $1 \%$ of probability for the observed variables of fresh mass of the aerial part (FMAP), number of leaves (NL) and number of viable plants per plot (NVPP). In the second cycle of culture, the same variables of the first cycle obtained significance, adding the variable stem length (SL), which previously had not obtained significant differentiation by the Tukey test.

Table 1 - Significance level (SL) and coefficient of variation (CV) for the variables fresh mass of the aerial part (FMAP), fresh roots mass (FRM), number of leaves $(\mathrm{NL})$, stem length $(\mathrm{SL})$ and number of viable plants per plot (NVPP) in the first and second lettuce cycle.

\begin{tabular}{ccccc}
\hline \multirow{2}{*}{ Variables } & \multicolumn{2}{c}{$\mathbf{1}^{\mathbf{0}}$ Cycle } & \multicolumn{2}{c}{$\mathbf{2}^{\mathbf{0}}$ Cycle } \\
\cline { 2 - 5 } & SL & CV (\%) & SL & CV (\%) \\
\hline FMAP & $0.0022^{* *}$ & 11.72 & $0.0001^{* *}$ & 10.19 \\
FRM & $0.5178 \mathrm{~ns}$ & 22.72 & $0.5178 \mathrm{~ns}$ & 27.72 \\
NL & $0.0024^{* *}$ & 5.22 & $0.0000^{* *}$ & 3.96 \\
SL & $0.1207 \mathrm{~ns}$ & 10.64 & $0.0000^{* *}$ & 5.82 \\
NVPP & $0.0001^{* *}$ & 3.37 & $0.0002^{* *}$ & 3.61 \\
\hline
\end{tabular}

Significance level values followed by the initials "ns" did not obtain significance and the values followed by two asterisks $\left(^{* *}\right)$ obtained significance at $1 \%$ probability, using the Tukey test.

Source: Sousa et al. (2020).

In the data obtained from the coefficient of variation for the variables FMAP, NL, SL and NVPP, the data dispersion is considered average and the experimental precision is optimal. In the variable fresh roots mass, for which there was no significance by the Tukey test, the data dispersion was considered high and the accuracy regular (PIMENTEL GOMES; GARCIA, 2002).

The results of the averages obtained and the statistical analysis carried out for the biomass parameters of the lettuce in the two cycles are shown in Table 2. 
Table 2 - Test of means for the variables fresh mass of the aerial part (FMAP), fresh roots mass (FRM), number of leaves (NL), stem length (SL) and number of viable plants per plot (NVPP), in the two cycles of lettuce.

\begin{tabular}{|c|c|c|c|c|c|}
\hline \multicolumn{6}{|c|}{$1^{\circ}$ Cycle } \\
\hline \multirow{2}{*}{ Treatments } & FMAP & FRM & NL & SL & NVPP \\
\hline & $\mathrm{g}$ & $\mathrm{g}$ & qty & $\mathrm{cm}$ & qty \\
\hline $\mathrm{T} 1$ & $235.75 a$ & $0.008 \mathrm{a}$ & $19.37 \mathrm{a}$ & $4.31 \mathrm{a}$ & $26.75 \mathrm{a}$ \\
\hline $\mathrm{T} 2$ & $220.56 a$ & 0.009 a & $17.87 \mathrm{~b}$ & $4.58 \mathrm{a}$ & $25.75 \mathrm{a}$ \\
\hline T3 & $182.14 \mathrm{~b}$ & $0.008 \mathrm{a}$ & $17.37 \mathrm{~b}$ & $4.85 \mathrm{a}$ & $24.00 \mathrm{~b}$ \\
\hline \multicolumn{6}{|c|}{$2^{\circ}$ Cycle } \\
\hline T1 & $254.17 \mathrm{a}$ & $0.008 \mathrm{a}$ & $20.37 \mathrm{a}$ & $5.33 \mathrm{a}$ & $26.50 \mathrm{a}$ \\
\hline $\mathrm{T} 2$ & $217.72 b$ & $0.009 a$ & $17.87 b$ & $4.37 b$ & $24.75 b$ \\
\hline T3 & $185.86 \mathrm{c}$ & $0.008 \mathrm{a}$ & $17.50 \mathrm{~b}$ & $4.27 \mathrm{~b}$ & $23.87 b$ \\
\hline
\end{tabular}

Means with the same letter in the column do not differ statistically, using the Tukey test at the level of $5 \%$ ( $p$ < 0.05). T1 - weekly spraying of efficient microorganisms; T2 - weekly spraying of a mineral fertilizer; T3 - Witness, without any fertilization.

Source: Sousa et al. (2020).

In the first cycle, with respect to the variable fresh mass of the aerial part, the treatments that received weekly sprays of biological cocktail (EM) and mineral fertilizer presented the highest averages, equivalent to their fresh mass (235.75 and $220.56 \mathrm{~g}$, respectively).

The plants submitted to the T1 treatment responded with a greater number of leaves when compared to the other treatments and the highest number of viable plants per plot occurred for the T1 and T2 treatments. The means of the variables fresh roots mass and stem length did not present statistical difference.

The cultivar used in this experiment has as its main characteristic the curly and very consistent leaves, forming a compacted head. Therefore, it can be said that the number of leaves is directly linked to the formation of the head of the lettuce, what according to Queiroz et al. (2017), it is an important characteristic to cultivate, considering the consumer's preference for heads of larger volume and size when purchasing the product.

In the second cycle, the results proved to be advantageous for the treatment that received weekly spraying of the biological cocktail from Efficient Microorganisms. The variables fresh mass of the aerial part, number of leaves, length of stem and number of viable plants per plot obtained averages above the other treatments, not resulting in the observed root development variable (FRM). These results are similar to that obtained by Battisti and Santos (2011), who verified increases in the number of leaves, stem length and fresh mass of the aerial part of lettuce plants submitted to the treatment with Efficient Microorganisms.

As stated by Yuri et al. (2001), among the desirable characteristics of a cultivar, the length of the stem is important, since plant with an excessively long stem does not present good compactness and makes it difficult to process, affecting the final quality of the product. Resende et al. (2015), also stated that shorter lengths are desirable, both from a commercial point of view, and in relation to the material's resistance to premature flowering.

Considering the aforementioned statements, the result obtained for the treatment that received the application of the biological cocktail for the stem length and that stood out from the other treatments in the second cycle would not be a positive result under this perspective. However, the means for this variable, which were $4.31 \mathrm{~cm}$ and $5.33 \mathrm{~cm}$, in the first and second cycles, respectively, are considered 
adequate, according to Resende et al. (2008), who reported that the appropriate length of the lettuce stem is up to $6 \mathrm{~cm}$, being acceptable up to $9 \mathrm{~cm}$.

The results were not conclusive in relation to the variable FRM, the harvest may have been a factor that interfered, as it was observed that much of the root system remained in the soil when performing the manual plucking of plants.

In the second cycle, it was observed that the T1 treatment (Efficient Microorganisms) provided higher values of fresh mass of the aerial part, number of leaves, length of the stem and quantity of viable plants per plot, differing significantly from the other treatments (conventional fertilization and without fertilization) ). This was due to the progressive action on the soil involving EMs; according to Andrade (2011), these microorganisms require a certain amount of time to enable system stability as well as to guarantee greater uniformity in production.

Based on the fresh mass of the aerial part of all plants sampled in the different treatments and the size of the area corresponding to the plots, productivity was estimated in the two crop cycles (FIGURE 1).

Figure 1 - Estimated productivity in $\mathrm{t} \mathrm{ha}^{-1}$, in the two crop cycles, according to the treatments applied.

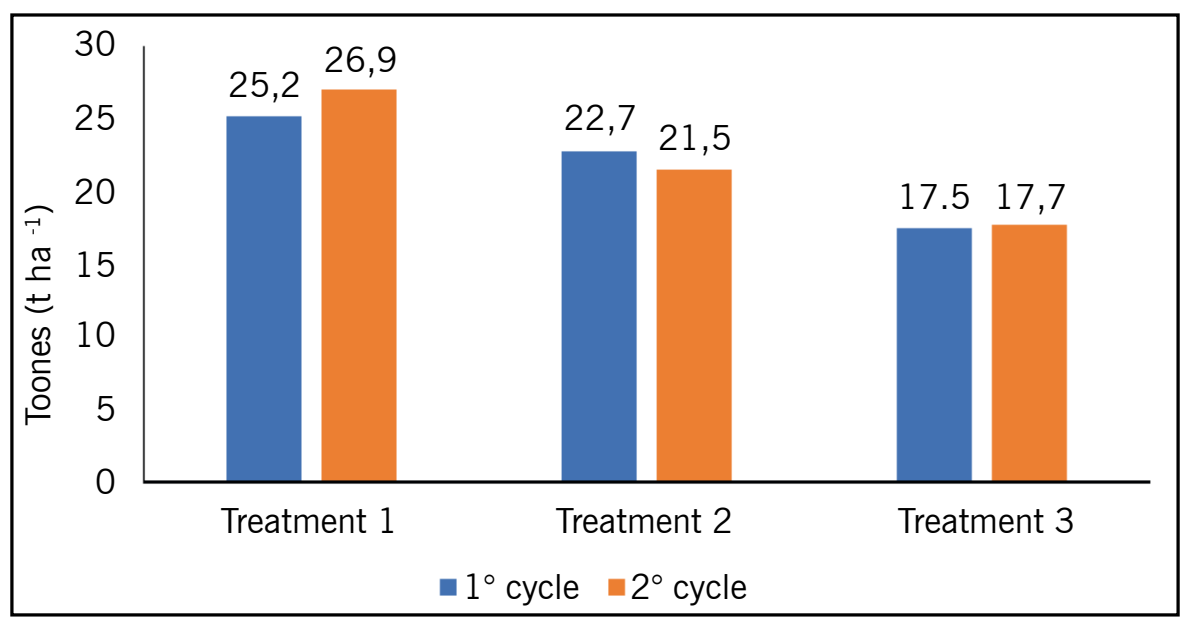

Treatment 1 - Weekly application of Efficient Microorganism; Treatment 2 - Weekly application of mineral fertilizer; Treatment 3 - Control, without any fertilization.

Source: Sousa et al. (2020).

The T1 treatment, application of Efficient Microorganism, obtained greater fresh mass of the aerial part of the plants sampled in the two cycles, resulting in greater productivity in tons/hectare. Regarding the two cycles, it is possible to observe that in the T1 treatment, the lettuce productivity increased in relation to the first cycle, while in the T2 treatment, the result behaved in a decreasing way and in T3 there were no great variations.

This increase in productivity for the treatment with Efficient Microorganisms may be related to what is stated by Osorio Filho et al. (2015), that the EMs favor the synthesis of nutrients necessary for plant growth and production, moreover, this complex of efficient microorganisms has substances that act in a similar way to phytohormones, promoting physiological responses in plants (OLIVEIRA, 2006). Thus, it is very likely that the greater vegetative growth presented by the T1 treatment at the end of the experiment is related to these factors. 


\section{Conclusions}

The biological cocktail, from Efficient Microorganisms, proved to be an efficient and effective technical application for the cultivation of American lettuce. The plants submitted to this product obtained a greater increase in the biomass of the aerial part, resulting in a greater productivity of the culture. Efficient Microorganism is a product that can be used as a biofertilizer in lettuce cultivation, diversifying from other effective agroecological techniques.

\section{Microrganismos Eficientes no cultivo de alface}

\section{Resumo}

Os Microrganismos Eficientes se mostram como uma técnica eficaz, alternativa, sustentável, segura e de baixo custo para aumentar a produtividade dos alimentos orgânicos, sendo sua utilização uma boa opção de manejo agroecológico. Nesse contexto, este trabalho teve como objetivo principal analisar a eficiência da aplicação de um coquetel biológico proveniente de Microrganismos Eficientes no cultivo de alface. Na captura dos Microrganismos Eficientes e fabricação do coquetel biológico, utilizou-se da metodologia disposta nas fichas agroecológicas do Ministério da Agricultura, Pecuária e Abastecimento. 0 delineamento experimental adotado foi o de blocos casualizados, com 8 blocos e 3 tratamentos. 0 tratamento T1, aplicação dos Microrganismos Eficientes, obteve maior massa fresca da parte aérea das plantas amostradas nos dois ciclos, resultando em uma maior produtividade em ton ha-1. Os resultados se mostraram vantajosos para a produtividade da alface que recebeu aplicação do coquetel biológico proveniente de Microrganismos Eficientes, quando analisados os parâmetros de biomassa.

Palavras-chave: Lactuca sativa. Produção orgânica. Coquetel biológico.

\section{References}

ANDRADE, F. M. C. Cadernos dos microrganismos eficientes (EM): Instruções práticas sobre o uso ecológico e social do EM. 2 ed. Viçosa: [s.n.], 2011.32 p. Disponível em: <http://estaticog1.globo.com/ 2014/04/16/caderno-dos-microrganismos-eficientes.pdf>. Acesso em: 10 mar. 2019.

BATTISTI, M. B.; SANTOS, M. G. Avaliação da eficiência da aplicação de microrganismos eficientes EM・1 ${ }^{\circledast}$ em cultivo de alface. 2011. 41 p. Monografia (TCC) - Curso de Tecnologia em Gestão Ambiental, Universidade Tecnológica Federal do Paraná, Medianeira, 2011. Disponível em: <http://repositorio.roca.utfpr.edu.br/jspui/handle/1/459>. Acesso em: 10 mar. 2019.

FERREIRA, D. F. Sisvar: a computer statistical analysis system. Ciência e Agrotecnologia, v. 35, n. 6, p. 1039-1042, nov./dez. 2011.

INAGAKI, A. M.; DIAMANTE, M. S.; SEABRA JÚNIOR, S.; NUNES, M. C. M.; SILVA, M. B.; NEVES, S. M. A. S. Identificação, mapeamento e comercialização de alface em Cáceres, Mato Grosso Brasil. Horticultura Brasileira, v. 29, n. 2, p. 353-361, 2011. 
LEITE, C. D.; MEIRA, A. L.; MOREIRA, V. R. R. Uso de microrganismos eficientes em Plantas, Sementes e Solo. Fichas Agroecológicas do Ministério da Agricultura, Pecuária e Abastecimento, n. 32, 2016.

LEITE, C. D.; MEIRA, A. L. Preparo de microrganismos eficientes (EM). Fichas Agroecológicas do Ministério da Agricultura, Pecuária e Abastecimento, n. 31, 2016.

MITSUIKI, C. Efeito de sistemas de preparo de solo e do uso de Microrganismos Eficazes nas propriedades físicas do solo, produtividade e qualidade de batata. 2006. 98 p. Dissertação (Mestrado em Fitotecnia) - Escola Superior de Agricultura Luiz de Queiroz, Universidade de São Paulo, Piracicaba, 2006. Disponível em: <http://www.teses.usp.br/teses/disponiveis/11/11136/tde26022007-151401/pt-br.php>. Acesso em: 10 mar. 2019.

OLIVEIRA, S. A. S. Aplicação foliar de nitrato e de Microrganismos Eficazes (EM) e seus efeitos sobre a partição de nutrientes em variedades de milho (Zea mays L.) cultivadas com resíduo industrial. 2006. 85 p. Dissertação (Mestrado em Ciências) - Universidade Federal Rural do Rio de Janeiro, Seropédica, 2006. Disponível em: <http://livros01.livrosgratis.com.br/cp006919.pdf>. Acesso em: 10 mar. 2019.

OSORIO FILHO, B. D.; NETA, A. N. O.; ROSA, C. A.; HUFF, F. H.; RICHA, G. C.; DAMASCENO, R.; SÁ, E. L. S. Capacidade de rizóbios na promoção de crescimento de plantas de alface. In: V CONGRESSO LATINOAMERICANO DE AGROECOLOGIA, 2015. Anais... [s.I]: [s.n], 2015. p. 1-5. Disponível em: <http://sedici.unlp.edu.ar/handle/10915/53104>. Acesso em: 10 mar. 2019.

PEREIRA, E. G.; DIAS, A. S.; PEREIRA, D. S.; SANTOS, J. S. Desenvolvimento inicial do Rabanete submetido à adubação orgânica e microrganismos eficientes. In: SIMPÓSIO DE PÓS-GRADUAÇÃO EM AGROECOLOGIA, 4., 2015. Anais... Viçosa: Universidade Federal de Viçosa, 2015. p. 10-13. Disponível em: <http://www.simposioppgagroecologia.ufv.br/wp-content/uploads/Anais-do-IV-SIMPA-20152.pdf>. Acesso em: 10 mar. 2019.

PEREIRA, T. G.; SILVA, S.; MORAIS, E. G.; LOPES, M. A. P.; PEREIRA, J. G.; GONÇALVES, L. D. Utilização de microrganismos eficientes (EM) na produção de alimentos orgânicos. In: SEMANA DE CIÊNCIA E TECNOLOGIA DO IFMG, 7. Anais... Bambuí: IFMG, 2014. p. 1-5. Disponível em: <http://bambui. ifmg.edu.br/jornada_cientifica/2014/resumos/Agronomia/Utiliza\%C3\%A7\%C3\%A30\%20de\%20 Microrganismos\%20eficientes\%20(EM)\%20na\%20produ\%C3\%A7\%C3\%A30\%20de\%20.pdf>. Acesso em: 10 mar. 2019.

PIMENTEL GOMES, F.; GARCIA, C. H. Estatística aplicada a experimentos agronômicos e florestais: Exposição com exemplos e orientações para uso de aplicativos. Piracicaba: Fealq, 2002. 309 p.

PUGAS, A. S.; GOMES, S. S.; DUARTE, A. P. R.; ROCHA, F. C. R.; SANTOS, T. E. M. S. Efeito dos microrganismos eficientes na taxa de germinação e no crescimento da Abobrinha (Curcubita PepoL.). Cadernos de Agroecologia, [s.I.], v. 8, n. 2, p.1-5, nov. 2013.

QUEIROZ, A. A.; CRUVINEL, V. B.; FIGUEIREDO, K. M. E. Produção de alface americana em função da fertilização com organomineral. Enciclopédia Biosfera, v. 14, n. 25, p.1053-1063, 2017. 
RESENDE, G. M.; YURI, J. E.; COSTA, N. D.; GOMES, A. S. Alface: Qual cultivar?. 2015. Embrapa Semiárido. Disponível em: <https://www.alice.cnptia.embrapa.br/bitstream/doc/1013085/1/ Milanez.pdf > . Acesso em: 10 mar. 2019.

RESENDE, G. M.; YURI, J. E.; MOTA, J. H.; SOUZA, R. J. Resposta da alface tipo americana a doses e épocas de aplicação de Molibdênio em cultivo de inverno. Ciência e Agrotecnologia, v. 32, n. 1, p.143-148, 2008.

SAMPAIO, B. S. Biofertilizante na produção de Alface. 2013. 85 p. Dissertação (Mestrado em Agricultura Tropical) - Centro Universitário Norte do Espírito Santo, Universidade Federal do Espírito Santo, São Mateus, 2013. Disponível em: <http://repositorio.ufes.br/handle/10/5196>. Acesso em: 10 mar. 2019.

SIQUEIRA, A. P. P.; SIQUEIRA, M. Bokashi: adubo orgânico fermentado. Niterói: Programa Rio Rural, 2013. 18 p. Disponível em: <http://www.pesagro.rj.gov.br/downloads/riorural/40_Bokashi_Adubo_ organico_fermentado.pdf>. Acesso em: 10 mar. 2019.

YURI, J. E.; SOUZA, R. J.; FREITAS, S. A. C.; RODRIGUES JÚNIOR, J. C.; MOTA, J. H. Comportamento de cultivares de alface tipo americana em Boa Esperança. Horticultura Brasileira, v. 20, n. 2, p.229232, 2001.

Received in: July 18, 2019

Accepted in: September 3, 2019 